\title{
PENGENDALIAN EROSI SECARA VEGETATIF MENGGUNAKAN RUMPUT PAIT (Axonopus compressus) DAN RUMPUT ALANG-ALANG (Imperata cylindrica) PADA TANAH ORDO ULTISOLS \\ (Vegetative Erosion Control Using Carpet Grass (Axonopus compressus) and Reed Grass (Imperata cylindrica) in Ordo of Ultisols)
}

\author{
Safriani $^{1}$, Dewi Sri Jayanti ${ }^{1}$, Syahrul ${ }^{1 *}$ \\ ${ }^{1}$ Program Studi Teknik Pertanian, Fakultas Pertanian, Universitas Syiah Kuala
}

\begin{abstract}
Abstrak. Perubahan penggunaan lahan pada lahan miring menyebabkan tanah lebih mudah tererosi. Salah satu upaya penanganan erosi dapat dilakukan dengan metoda vegetatif yaitu menggunakan rumput pait (Axonopus compressus) dan rumput alang-alang (Imperata cylindrical) pada tanah ordo ultisols. Oleh karena itu, penelitian ini bertujuan untuk mengetahui kemampuan rumput pait dan rumput alang-alang dalam mengurangi erosi tanah pada kemiringan yang berbeda. Penelitian ini dilakukan di Laboratorium Konservasi Tanah dan Air Fakultas Pertanian Universitas Syiah Kuala dengan menggunakan Rainfall Simulator yang ditata dalam kotak uji. Faktor yang digunakan pada penelitian ini adalah kemiringan (main plot factor) dan jenis rumput (sub plot factor). Perlakuan dalam penelitian ini terdiri dari 3 taraf kemiringan, yaitu $5^{\circ}, 10^{\circ}$, serta $15^{\circ}$ dan 3 taraf vegetasi, yaitu tanpa rumput, rumput pait dan rumput alang-alang. Hasil penelitian diperoleh besar erosi yang terjadi pada kemiringan $5^{\circ}$ dengan vegetasi tanah tanpa rumput $(0,425$ ton/ha/tahun), rumput pait $(0,375$ ton/ha/tahun), dan rumput alang-alang $\left(0,125\right.$ ton/ha/tahun). Pada kemiringan $10^{\circ}$ dengan vegetasi tanah tanpa rumput $(1,102$ ton/ha/tahun), rumput pait (0,305 ton/ha/tahun), dan rumput alang-alang (0,414 ton/ha/tahun). Pada kemiringan $15^{\circ}$ dengan vegetasi tanah tanpa rumput $(2,217$ ton/ha/tahun), rumput pait $(0,451$ ton/ha/tahun), dan rumput alang-alang (0,858 ton/ha/tahun). Hasil pengujian dengan analisis sidik ragam (Ansira) bahwa terdapat perlakuan yang berpengaruh nyata. Perlakuan yang berpengaruh nyata tersebut diantaranya kemiringan, vegetasi, dan kombinasi antara kemiringan dan vegetasi. Sedangkan hasil dari uji lanjut BNT (Beda Nyata Terkecil) menunjukkan adanya perbedaan yang signifikan pada beberapa perlakuan.
\end{abstract}

Kata kunci: Erosi, Kemiringan Lahan, Rumput Pait, Rumput Alang-alang.

\begin{abstract}
Land use change in the sloping land cause soil erosion easier. One efforts for erosion countermeasure can be made with a vegetative method using carpet grass (Axonopus compressus) and reed grass (Imperata cylindrical) in ordo of ultisols. Therefore this research aim to determine the ability of carpet grass and reed grass in overcoming soil erosion at different slope of land. This research was done in Soil and Water Conservation Laboratory Faculty of Agriculture, University of Syiah Kuala using with Rainfall Simulator arranged in a test box. Factors used in this research is the slope (main plot factor) and type of grass (sub plot factor). The treatment of this research consist of 3 levels slope, namely $5^{\circ}, 10^{\circ}$ and $15^{\circ}$ and 3 levels vegetation, namely land without grass, carpet grass and reed grass. The research results are erosion in the slope of $5^{\circ}$ with land without grass ( 0.425 ton/hectare/year), with carpet grass $(0.375$ ton/hectare/year $)$, and reed grass $(0.125$ ton/hectare/year $)$. In the slope of $10^{\circ}$ with land without grass (1.102 ton/hectare/year), with carpet grass $(0.305$ ton/hectare/year $)$, and reed grass $\left(0.414\right.$ ton/hectare/year). In the slope of $15^{\circ}$ with land without grass $(2.217$ ton/hectare/year $)$, with carpet grass ( 0.451 ton/hectare/year), and reed grass ( 0.858 ton/hectare/year). The result of variance analysis (Anova) show that there are treatments with significant effect. The treatment with significant effect are slope, vegetation, and combination of slope and vegetation. Results from continued test with LSD (Least Significant Difference) show significant difference among treatments.
\end{abstract}

Keywords: Erosion, Slope, Carpet Grass, Reed Grass

\section{PENDAHULUAN}

Perubahan penggunaan lahan pada lahan miring menyebabkan tanah menjadi lebih mudah terdegradasi oleh erosi tanah. Erosi tanah merupakan kejadian alam yang terjadi dipermukaan bumi dan umumnya disebabkan oleh air. Besarnya erosi tanah sangat tergantung dari faktor-faktor terjadinya erosi tersebut.Secara umum, terjadinya erosi dipengaruhi oleh faktor-faktor seperti iklim, topografi, karakteristik tanah, vegetasi penutup tanah dan manusia.

Erosi terjadi karena dua penyebab utama yaitu erosi karena sebab alamiah dan erosi karena aktivitas manusia. Erosi alamiah dapat terjadi karena proses pembentukan tanah dan 
proses erosi yang terjadi untuk mempertahankan keseimbangan tanah secara alami. Sedangkan erosi karena kegiatan manusia kebanyakan disebabkan oleh terkelupasnya lapisan tanah bagian atas akibat cara bercocok tanam yang tidak mengindahkan kaidah-kaidah konservasi tanah (Asdak, 2007).

Mengingat bahaya erosi yang merugikan lingkungan perlu dilakukan pencegahan erosi yang dapat dilakukan dengan metode konservasi vegetatif seperti menanam rumput. Berdasarkan penelitian yang dilakukan oleh Arnita (2012) menunjukkan adanya pengaruh kerapatan tanaman, intensitas hujan, dan kemiringan lereng terhadap erosi yang terjadi. Semakin rapat vegetasi penutup tanah yang digunakan, tanah yang tererosi semakin sedikit dibandingkan dengan vegetasi penutup tanah yang ditanam secara acak.

Penelitian tentang penggunaan berbagai jenis rumput untuk penanganan erosi di Indonesia sudah banyak dilakukan, dari beberapa penelitian yang dilakukan didapat nilai erosi yang bervariasi pada setiap perlakuan dengan kondisi lahan yang berbeda. Maka dari itu penelitian ini bermaksud untuk melihat kemampuan rumput pait (Axonopus compressus) dalam mengurangi erosi tanah serta membandingkannya dengan rumput alang-alang (Imperata cylindrica) yang biasa tumbuh liar.

\section{METODE PENELITIAN}

\section{Alat dan Bahan}

Peralatan yang digunakan terdiri dari rainfallsimulator, kotak uji, wadah penampung, ring sampeltanah, gelas ukur, timbangan digital, stopwatch, alat tulis dan lain-lain. Bahan yang digunakan terdiri dari air, tanah, rumput pait (Axonopus compressus) dan rumput alangalang (Imperata cylindrica).

\section{Rancangan Penelitian}

Penelitian ini menggunakan metode eksperimen yang ditata dalam bentuk Rancangan Faktorial (Factorial Experimental Design) dengan Pengaruh Tunggal, Utama dan Interaksi (Hanafiah, 2011). Terdapat dua faktor percobaan yang akan dilihat pengaruhnya terhadap erosi yang terjadi. Faktor pertama merupakan kemiringan (main plot factor)dan jenis rumput (vegetasi) sebagai faktor kedua (sub plot factor).

\section{Prosedur Penelitian}

Pada tahap persiapan penelitian dilakukan pengambilan sampel tanah untuk dianalisis tanah di laboratorium. Plot penelitian dibuat untuk ketiga perlakuan, kemudian dilakukan penanaman rumput pait dan rumput alang-alang serta dimasukkan tanah kosong tanpa rumput ke dalam plot selama 1 bulan. Lalu dilakukan perakitan dan penyiapan 1 set rainfall simulator yang akan digunakan untuk mengukur intensitas curah hujan dan laju erosi.

Pengukuran curah hujan dilakukan dengan menggunakan alat penakar curah hujan manual (observatorium) yang ditempatkan di dalam rainfall simulator, pencatatan dilakukan setiap pemberian hujan dengan durasi selama 5 menit pada tekanan $15 \mathrm{kPa}$.Curah hujan yang jatuh pada kotak uji beserta sedimennya ditampung ke tempat penampungan erosi dan diendapkan untuk membedakan erosi dan air limpasan.

\section{Teknik Analisa Data}

Analisis tanah dilakukan di laboratorium yang terdiri atas tekstur tanah, struktur tanah, bobot isi tanah (Bulk Density), permeabilitas dan bahan organik tanah.Aliran permukaan ditentukan dengan mengukur volume air yang masuk ke tempat penampungan dan diukur dengan menggunakan gelas ukur pada setiap pemberian hujan yang disimulasikan.

Erosi tanah dapat diukur dengan menimbang tanah yang terangkut akibat aliran permukaan (berdasarkan berat kering). Tanah yang tertampung pada tempat penampung 
diendapkan lalu dipanaskan sebesar $105^{\circ} \mathrm{C}$ selama 24 jam untuk menguapkan air yang ada pada tanah, setelah itu tanah tersebut dikeringkan dan ditimbang menggunakan timbangan analitik. Model parametrik untuk memprediksi erosi dapat digunakan persamaan USLE yaitu sebagai berikut:

$$
\text { A = R.K.L.S.C.P }
$$

Dimana :

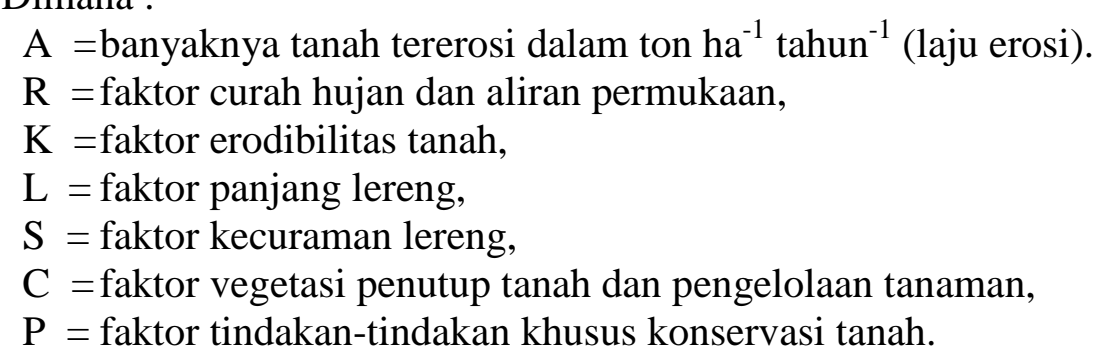

Untuk mengetahui pengaruh faktor perlakuan terhadap erosi diuji dengan analisis sidik ragam (ANSIRA) atau uji Fisher (F) pada probabilitas atau tingkat peluang 0,05. Sedangkan untuk melihat perbedaan rata-rata respon perlakuan, jika perlakuan berpengaruh nyata akan dilanjutkan dengan uji Beda Nyata Terkecil (BNT) pada $\alpha=0,05$.

\section{HASIL DAN PEMBAHASAN}

\section{Tanah}

Berdasarkan analisis Laboratorium Penelitian Tanah dan Tanaman serta Laboratorium Fisika Tanah dan Lingkungan didapatkan hasil analisis seperti Tabel 1 berikut.

Table 1. Hasil Analisis Laboratorium

\begin{tabular}{llcl}
\hline No. & \multicolumn{1}{c}{ Hasil Analisis } & Nilai & Keterangan \\
\hline 1. & C-organik & $0,77 \%$ & \\
\hline 2. & Kelas tekstur & & Lempung (loam) \\
& Fraksi pasir (sand) & $42 \%$ & \\
& Fraksi debu (silt) & $48 \%$ & \\
& Fraksi liat (clay) & $10 \%$ & \\
\hline 3. & Struktur & & Granular \\
\hline 4. & Permeabilitas tanah & $5,91 \mathrm{~cm} / \mathrm{jam}$ & Kriteria agak lambat \\
\hline 5. & Bulk density & 1,29 gram $/ \mathrm{cm}^{3}$ & Kriteria berat \\
\hline 6. & Porositas total & $45,56 \%$ & Kriteria kurang baik \\
\hline
\end{tabular}

Sumber: Analisis Laboratorium (2016)

\section{Curah Hujan}

Berdasarkan data hasil pengukuran curah hujan dengan menggunakan alat penakar curah hujan manual (observatorium) yang ditempatkan didalam rainfall simulator, didapat intensitas rata-rata curah hujan sebesar $38,76 \mathrm{~cm} / \mathrm{jam}$. Nilai ini didapat berdasarkan pengukuran dengan tekanan yang digunakan sebesar $15 \mathrm{kPa}$ sebanyak lima kali ulangan dengan durasi 5 menit. Intensitas curah hujan yang didapat sebesar 38,76 cm/jam atau 387,6 $\mathrm{mm} / \mathrm{jam}$ termasuk ke dalam kriteria sangat lebat karena mempunyai intensitas hujan lebih dari 50 mm/jam (Arsyad, 2010). 


\section{Aliran Permukaan}

Pengaruh penggunaan vegetasi yang berbeda dengan beberapa jenis kemiringan lereng terhadap laju aliran permukaan pada intensitas $38,76 \mathrm{~cm} / \mathrm{jam}$ dengan durasi 5 menit terdapat pada Tabel 2 berikut.

Tabel 2. Pengaruh Penggunaan Jenis Rumput (Vegetasi) Berbeda dengan Beberapa Kemiringan Lereng Terhadap Laju Aliran Permukaan

\begin{tabular}{clc}
\hline Kemiringan $\left({ }^{\circ}\right)$ & \multicolumn{1}{c}{ Jenis Rumput } & $\begin{array}{c}\text { Rerata Aliran Permukaan } \\
(\mathbf{m m} / \mathbf{j a m})\end{array}$ \\
\hline \multirow{2}{*}{5} & Tanpa rumput & 127,9 \\
& Rumput pait & 141,3 \\
& Rumput alang-alang & 89,1 \\
\hline \multirow{2}{*}{10} & Tanpa rumput & 168,7 \\
& Rumput pait & 100 \\
& Rumput alang-alang & 111,5 \\
\hline \multirow{2}{*}{15} & Tanpa rumput & 197,32 \\
& Rumput pait & 132,8 \\
& Rumput alang-alang & 137,8 \\
\hline
\end{tabular}

Sumber: Data Penelitian (2016)

Berdasarkan tabel diatas tentang pengaruh penggunaan jenis rumput (vegetasi) yang berbeda dengan beberapa jenis kemiringan lereng terhadap laju aliran permukaan dengan durasi hujan 5 menit dapat dilihat bahwa mengalami perbedaan yang bervariasi. Semakin tinggi kemiringannya, semakin besar aliran permukaan yang didapat. Jenis rumput atau vegetasi yang digunakan juga menentukan besarnya aliran permukaan, vegetasi tanpa menggunakan rumput menghasilkan rata-rata aliran permukaan yang lebih besar dibandingkan vegetasi yang menggunakan rumput pait dan rumput alang-alang. Selain itu kadar air tanah sebelum pengujian dilakukan juga sangat memengaruhi besarnya aliran permukaan yang didapat.

Berikut merupakan grafik yang menunjukkan besarnya rata-rata aliran permukaan yang didapat pada penelitian ini.

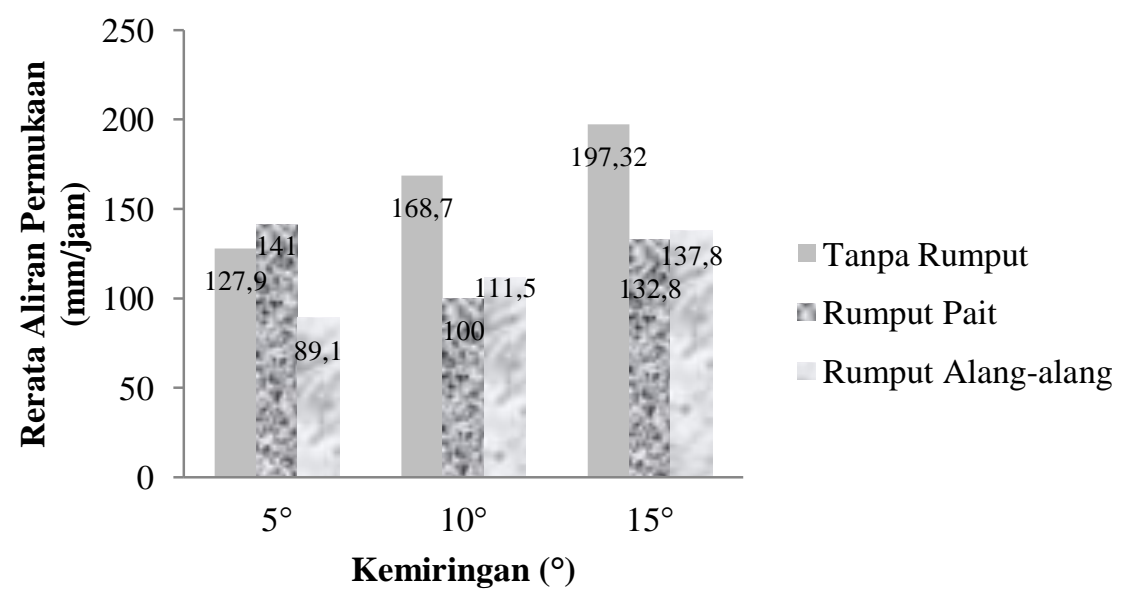

Gambar 1. Rerata Aliran Permukaan yang Terjadi dalam Waktu 5 menit 


\section{Erosi Berdasarkan Pengukuran Rainfall Simulator}

Pengukuran erosi tanah (gr) dilakukan berdasarkan berat kering tanah. Pengukuran dilakukan pada dua faktor percobaan yaitu kemiringan dan jenis vegetasi terdapat pada Tabel 3. berikut.

Tabel 3. Erosi Tanah (ton/ha/tahun)

\begin{tabular}{lcccc}
\hline \multirow{2}{*}{ Vegetasi ( R ) } & \multicolumn{3}{c}{ Kemiringan (K) } & \multirow{2}{*}{ Jlh Total } \\
\cline { 2 - 4 } & $\mathbf{5}^{\circ}$ & $\mathbf{1 0}^{\circ}$ & $\mathbf{1 5}^{\circ}$ & \\
\hline Tanpa Rumput & 0,425 & 1,102 & 2,217 & 3,744 \\
Rumput Pait & 0,375 & 0,305 & 0,451 & 1,131 \\
Rumput Alang-alang & 0,121 & 0,414 & 0,858 & 1,393 \\
\hline
\end{tabular}

Sumber : Data Penelitian (2016)

Besar erosi tanah yang terjadi pada beberapa perlakuan dengan kemiringan lereng serta vegetasi penutup tanah yang berbeda didapat nilai yang bervariasi. Penelitian ini dilakukan dalam waktu 5 menit. Berikut merupakan grafik yang menunjukkan hasil pengukuran erosi.

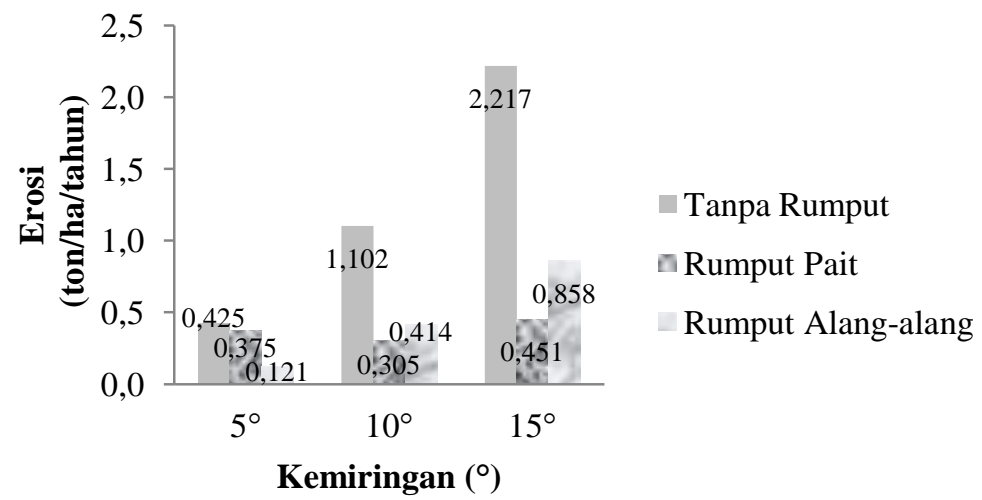

Gambar 2. Erosi Tanah (ton/ha/tahun) yang Terjadi pada Beberapa Kemiringan dan Vegetasi Penutup Tanah yang Berbeda

Berdasarkan grafik pada Gambar 2. diatas dapat dilihat bahwa semakin tinggi kemiringan, erosi tanah yang terukur umumnya juga lebih besar. Erosi tertinggi terjadi pada perlakuan tanpa menggunakan rumput $\left(\mathrm{R}_{0}\right)$, selanjutnya perlakuan dengan menggunakan rumput alang-alang $\left(\mathrm{R}_{2}\right)$ dan kemudian perlakuan dengan menggunakan rumput pait $\left(\mathrm{R}_{1}\right)$.

\section{Erosi Berdasarkan Metode USLE}

Laju erosi dengan menggunakan metode USLE (Universal Soil Loss Equation) didapat dengan mengetahui nilai faktor-faktornya. Nilai A dari metode USLE dapat dilihat pada Tabel 4. berikut.

Tabel 4. Nilai A Tanah Tererosi (ton/ha/tahun)

\begin{tabular}{lrrrr}
\hline \multirow{2}{*}{ Vegetasi (R) } & \multicolumn{3}{c}{ Kemiringan $(\mathbf{K})$} & \multirow{2}{*}{ Jlh Total } \\
\cline { 2 - 4 } & $\mathbf{5}^{\circ}$ & $\mathbf{1 0}^{\circ}$ & $\mathbf{1 5}^{\circ}$ & \\
\hline Tanpa Rumput & 9,79 & 29,45 & 60,69 & 99,93 \\
Rumput Pait & 1,17 & 3,53 & 7,28 & 11,99 \\
Rumput Alang-alang & 2,741 & 8,245 & 16,994 & 27,98 \\
\hline
\end{tabular}

Sumber : Analisa Data (2016) 
Laju erosi atau banyaknya tanah yang tererosi (nilai A) dinyatakan dalam ton/ha/tahun. Nilai A yang didapat dari metode USLE dapat dilihat pada Tabel 4. Grafik berikut merupakan besar erosi yang terjadi dengan metode USLE. Pada gambar tersebut menunjukkan bahwa semakin besar kemiringan lereng, semakin tinggi tingkat erosi yang terjadi. Berikut merupakan grafik yang menunjukkan perbandingan nilai-nilai laju erosi (nilai A) yang didapat.

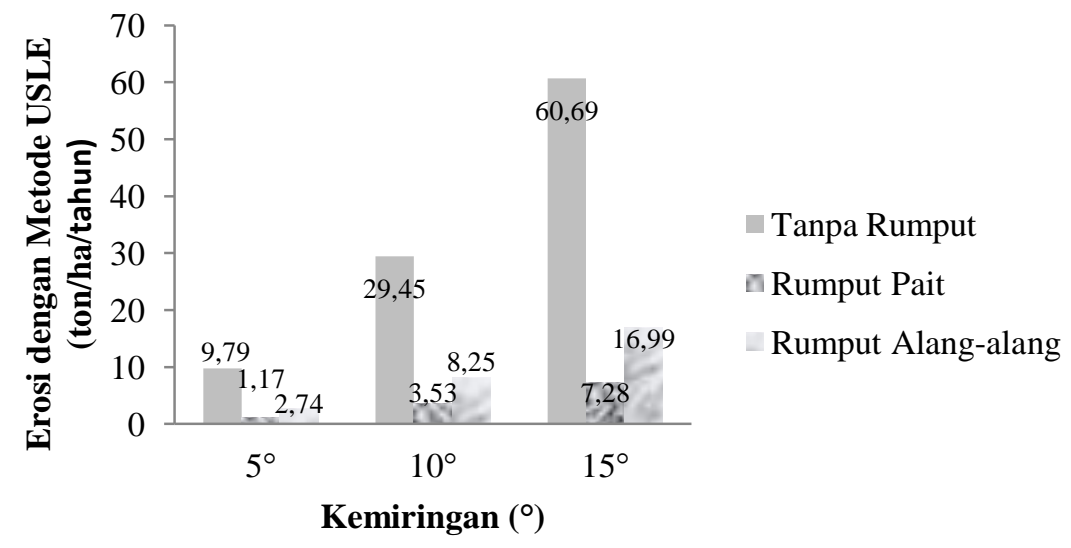

Gambar 3. Besar Erosi (nilai A) yang Didapat dengan Metode USLE

\section{Perbandingan Erosi Berdasarkan Persamaan USLE dan Rainfall Simulator}

Perhitungan laju erosi berdasarkan persamaan USLE didapat nilai yang lebih tinggi dibandingkan dengan pengukuran erosi menggunakan rainfall simulator. Perbandingan nilai laju erosi tersebut dapat dilihat pada Gambar 4.

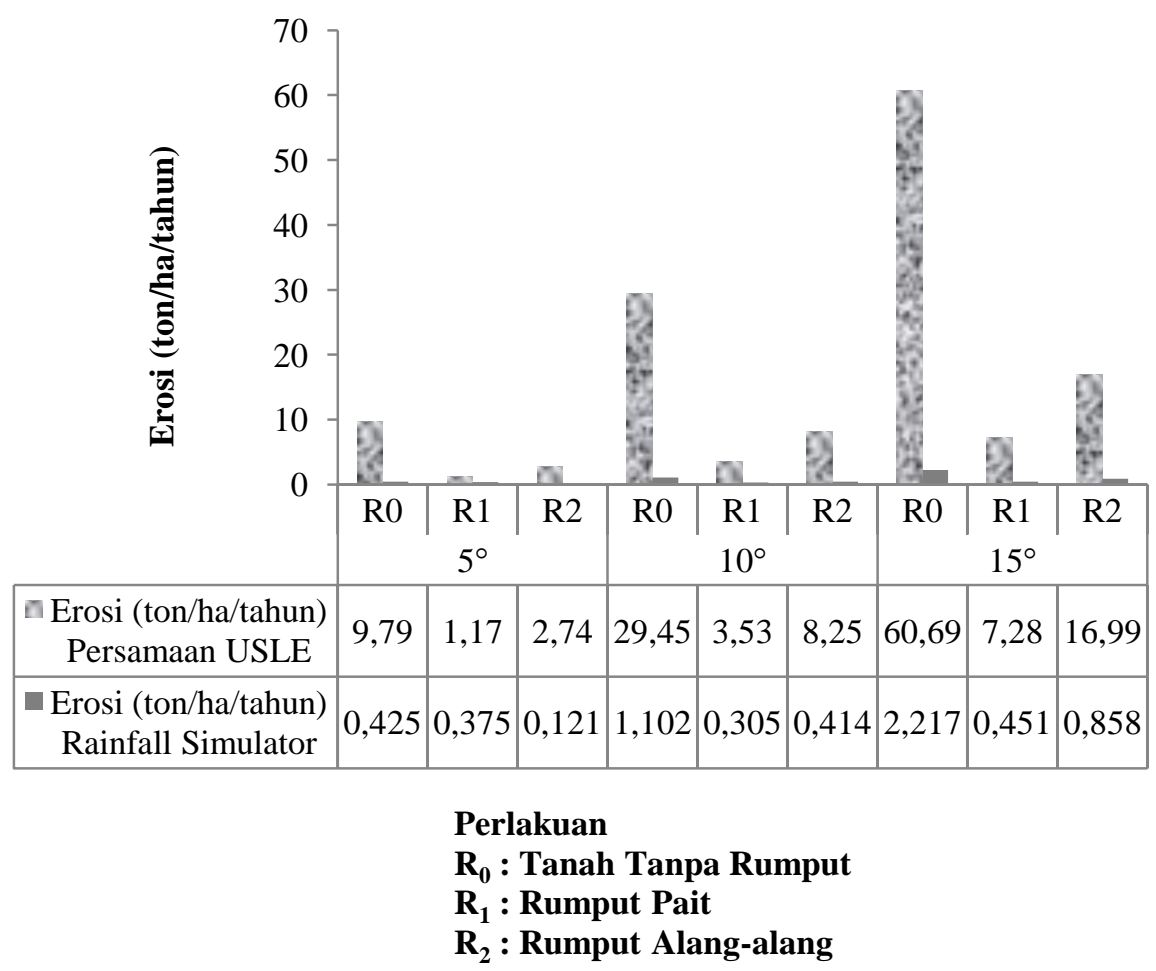

Gambar 4. Perbandingan Erosi Berdasarkan Persamaan USLE dengan Pengukuran Rainfall Simulator 


\section{Analisis Sidik Ragam (Ansira)}

Hasil pengujian data dengan menggunakan analisis sidik ragam (ansira) pada tingkat peluang 5\% atau 0.05 dapat dilihat pada Tabel 5 .

Tabel 5. Hasil Analisis Sidik Ragam (Ansira)

\begin{tabular}{lcrrrrc}
\hline $\begin{array}{c}\text { Sumber } \\
\text { Keragaman }\end{array}$ & DB & JK & \multicolumn{1}{c}{ KT } & F hitung & $\begin{array}{c}\text { F tabel } \\
(\mathbf{0 . 0 5})\end{array}$ \\
\hline Perlakuan & 8 & 76607,176 & 9575,897 & 13,917 & $*$ & 2,51 \\
Kemiringan & 2 & 27043,825 & 13521,913 & 19,651 & $*$ & 3,55 \\
Vegetasi & 2 & 32015,025 & 16007,513 & 23,264 & $*$ & 3,55 \\
K x R & 4 & 17548,326 & 4387,081 & 6,376 & $*$ & 2,93 \\
Galat & 18 & 12385,707 & 688,095 & & & \\
Total & 26 & 88992,883 & & & & \\
\hline
\end{tabular}

Sumber: Data Analisis (2016)

Keterangan : * = Berpengaruh Nyata.

Rancangan faktorial memungkinkan peneliti untuk meneliti pengaruh faktor utama, faktor kedua maupun faktor interaksi antara keduanya. Hasil pengujian dengan analisis sidik ragam (Ansira) atau analysis of variance (Anova) dapat dilihat pada Tabel 5. Pada tabel tersebut dapat dilihat bahwa terdapat perlakuan yang berpengaruh nyata dengan makna lain ada perlakuan yang pengaruhnya menonjol dibandingkan perlakuan lainnya. Perlakuan yang berpengaruh nyata tersebut diantaranya kemiringan, vegetasi, dan kombinasi anatara kemiringan dan vegetasi. Perlakuan dapat dikatakan berpengaruh nyata apabila nilai $\mathrm{F}$ hitung > (lebih besar) dari $\mathrm{F}$ tabel. Hal ini dapat dikatakan apabila perlakuan berpengaruh nyata maka $\mathrm{H}_{0}$ ditolak dan $\mathrm{H}_{1}$ diterima pada taraf uji 5\%, $\mathrm{H} 1$ merupakan hipotesis penelitian.

Dikarenakan hasil dari pada analisis sidik ragam menunjukkan adanya perlakuan yang berpengaruh nyata, maka dari itu pengujian dilanjutkan dengan uji lanjut BNT (Beda Nyata Terkecil) atau LSD (Least Significance Different). Pengujian ini bertujuan untuk memberikan informasi tentang ada atau tidak perbedaan antara perlakuan. Hasil dari uji lanjut BNT dapat dilihat pada Tabel 6 .

Tabel 6. Hasil Uji Lanjut BNT

\begin{tabular}{ccc}
\hline No. & Perlakuan & Nilai Rata-Rata \\
\hline 1 & $\mathrm{~K}_{1} \mathrm{R}_{0}$ & $37,4 \mathbf{a b}$ \\
2 & $\mathrm{~K}_{1} \mathrm{R}_{1}$ & $33 \mathbf{a b}$ \\
3 & $\mathrm{~K}_{1} \mathrm{R}_{2}$ & $10,67 \mathbf{a}$ \\
4 & $\mathrm{~K}_{2} \mathrm{R}_{0}$ & $96,87 \mathbf{c}$ \\
5 & $\mathrm{~K}_{2} \mathrm{R}_{1}$ & $26,8 \mathbf{a}$ \\
6 & $\mathrm{~K}_{2} \mathrm{R}_{2}$ & $36,4 \mathbf{a b}$ \\
7 & $\mathrm{~K}_{3} \mathrm{R}_{0}$ & $194,93 \mathbf{c}$ \\
8 & $\mathrm{~K}_{3} \mathrm{R}_{1}$ & $39,67 \mathbf{a b}$ \\
9 & $\mathrm{~K}_{3} \mathrm{R}_{2}$ & $75,4 \mathbf{b c}$ \\
\hline
\end{tabular}

Sumber: Data Analisis (2016)

Keterangan: Notasi yang sama dinyatakan tidak berbeda signifikan.

Pada tabel tersebut menunjukkan adanya perbedaan yang signifikan pada beberapa perlakuan yang ditandai oleh notasi yang berbeda disebelah kanan angka. Nilai rata-rata perlakuan yang diikuti oleh notasi yang sama dinyatakan tidak berbeda signifikan. 


\section{KESIMPULAN DAN SARAN}

\section{Kesimpulan}

1. Kemiringan yang berbeda dapat mempengaruhi besar erosi yang terjadi dengan menggunakan rumput pait dan rumput alang-alang. Dimana erosi yang didapat pada kemiringan $5^{\circ}$ dengan vegetasi tanah tanpa rumput $(0,425$ ton/ha/tahun), rumput pait (0,375 ton/ha/tahun), dan rumput alang-alang (0,125 ton/ha/tahun). Pada kemiringan $10^{\circ}$ dengan vegetasi tanah tanpa rumput (1,102 ton/ha/tahun), rumput pait $(0,305$ ton/ha/tahun), dan rumput alang-alang (0,414 ton/ha/tahun). Sedangkan pada kemiringan $15^{\circ}$ dengan vegetasi tanah tanpa rumput (2,217 ton/ha/tahun), rumput pait $(0,451$ ton/ha/tahun), dan rumput alang-alang $(0,858$ ton/ha/tahun).

2. Rumput pait dan rumput alang-alang mampu menahan laju erosi yang terjadi pada kemiringan yang berbeda dibandingkan tanah tanpa ditanami rumput. Hal ini dapat dilihat berdasarkan nilai laju erosi yang didapat dengan menggunakan vegetasi penutup tanah lebih kecil dari pada tanpa menggunakan vegetasi.

3. Terdapat hubungan antara kemiringan yang berbeda dengan kemampuan rumput pait dan rumput alang-alang serta tanah tanpa rumput untuk menahan laju erosi. Pernyataan ini berdasarkan hasil analisis sidik ragam yang berpengaruh nyata, ini membuktikan bahwa hipotesis diterima.

\section{Saran}

Adapun yang dapat disarankan untuk melanjutkan penelitian ini yaitu dengan melakukan penelitian lanjutan pada beberapa jenis tanah dengan kemiringan atau vegetasi penutup tanah yang berbeda serta dapat dilanjutkan dengan beberapa intensitas hujan yang lebih bervariasi.

\section{DAFTAR PUSTAKA}

Arnita, R. 2012. Kajian Pengaruh Kerapatan Tanaman Terhadap Erosi pada Lahan yang Ditanami Rumput Gajah. Skripsi. Jurusan Teknik Sipil, Fakultas Teknik, Universitas Syiah Kuala, Banda Aceh.

Arsyad, S. 2010. Konservasi Tanah dan Air. Penerbit IPB Press, Bogor.

Asdak, C. 2007. Hidrologi dan Pengelolaan Daerah Aliran Sungai. Gadjah Mada University Press, Yogyakarta.

Hanafiah, K. A. 2011. Rancangan Percobaan Teori dan Aplikasi. Rajawali Pers, Jakarta. 